\title{
VARIASI UKURAN TERHADAP KEKERASAN DAN LAJU KEAUSAN KOMPOSIT EPOXY ALUMUNIUM-SERBUK TEMPURUNG KELAPA UNTUK KAMPAS REM
}

\author{
FX. Kristianta ${ }^{1}$, Ario Kristian I T2, Imam Sholahuddin ${ }^{3}$ \\ 1,2,3 Jurusan Teknik Mesin, Fakultas Teknik, Universitas Jember. \\ Kampus Tegalboto, Jl. Kalimantan No. 37, Sumbersari, Kabupaten Jember, \\ Jawa Timur 68121 Telp.(0331) 484977 \\ E-mail: kristfx@yahoo.com
}

\begin{abstract}
The aim of this research was to investigate the influence of the particle size of coconut shell powder on hardness and wear rate om aluminium epoxy based composite. Experimental method was used in this study by using four configurations of particle size. The configuration includes comersial powder and particle size of $300 \mu \mathrm{m}, 425 \mu$ and $600 \mu \mathrm{m}$. The results showed that the highest and smallest hardness value obtained by $300 \mu \mathrm{m}$ of $63.67 \mathrm{~kg} / \mathrm{mm}^{2}$ and $600 \mu \mathrm{m}$ is $41.67 \mathrm{~kg}$, respectively. However, the highest and smallest wear rate obtained by $600 \mu \mathrm{m}$ is $8,70 \times 10-6 \mathrm{gram} / \mathrm{s} . \mathrm{mm}^{2}$ and $300 \mu \mathrm{m}$ is $1,17 \times 10^{-6} \mathrm{gram} / \mathrm{s} . \mathrm{mm}^{2}$, respectively. This phenomena occured due to the coconut shell powder size of $300 \mu \mathrm{m}$ is well and uniformly spread.
\end{abstract}

Keywords: brake shoes, composite, epoxy, coconut shell, aluminium.

\section{PENDAHULUAN}

Perkembangan industri otomotif meliputi komponen-komponen sepeda motor dengan berbagai macam produk dan merek menyebab kan persaingan antar produsen, baik dalam persaingan harga, mutu dan kualitas produk. Komponen sepeda motor yang sering diganti adalah kampas rem (Gambar 1).

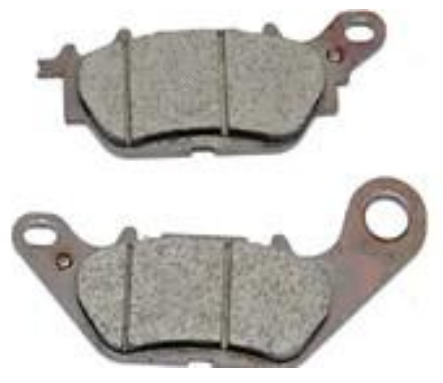

Gambar 1. Kampas Rem

Rem berfungsi untuk memperlambat atau menghentikan gerakan dari roda. Untuk mendapatkan hasil produksi optimal, maka akan dilakukan eksperimen dari faktor-faktor yang mempengaruhi nilai kekerasan kampas rem dan menentukan level dari faktor-faktor tersebut[1].

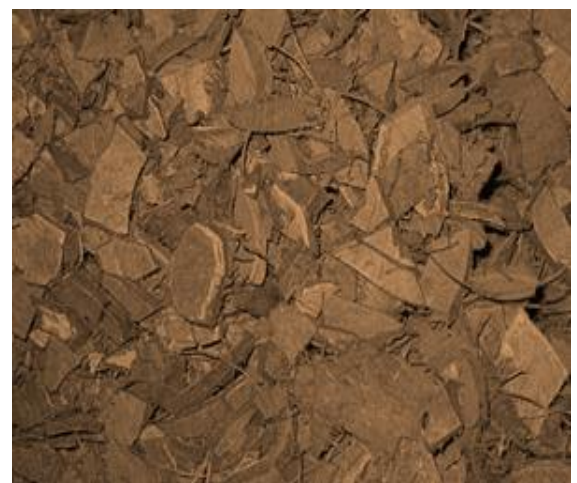

Gambar 2. Tempurung Kelapa

Kelapa merupakan komoditas yang berkembang di Kabupaten Jember (Regional Investment). Kelapa berpotensi sebagai alternative serat penguat bahan gesek nonasbes karena tempurung kelapa (Gambar 2) memiliki kekerasan 50 - 80 kgf.mm ${ }^{-2}$, keausan $5 \times 10^{-4}-5 \times 10^{-3} \mathrm{~mm}^{2} / \mathrm{kg}$ dan kerapatannya tinggi, serta serapan airnya rendah[2]. Penelitian pemanfaatan campuran serbuk tempurung kelapa-aluminium sebagai material alternatif kampas rem sepeda motor nonasbestos sudah dikembangkan oleh santoso dkk[3]. Dengan hasil penelitian pada komposisi serbuk tempurung kelapa $20 \%$, serbuk aluminium $40 \%$, resin $40 \%$ memiliki angka keausan sebesar $0,071.10-7 \mathrm{~mm} / \mathrm{kg}$ dan angka kekerasan sebesar 16,8 BHN. Pada 
penelitian ini akan dilakukan analisa terhadap ukuran serbuk tempurung kelapa pada komposit matrik epoxy berpenguat serbuk aluminium dan dilakukan pengujian kekerasan dan laju keausan.

\section{METODOLOGI PENELITIAN}

Penelitian ini menggunakan metode pene litian eksperimen dan merupakan penelitian deskriftif yaitu memaparkan secara jelas hasil eksperimen di laboratorium terhadap sejumlah benda uji. Penelitian ini diadakan untuk mengetahui pengaruh variasi ukuran serbuk tempurung kelapa berpenguat aluminium bermatriks epoksi pada kampas rem serta mengetahui nilai kekerasan dan nilai laju keausannya. Bahan-bahan yang akan digunakan dalam penelitian komposit epoxy aluminium-serbuk tempurung kelapa untuk kampas rem, yaitu: Serbuk Tempurung Kelapa, Serbuk Aluminium, Resin epoxy, dan Hardener. Alat-alat yang akan digunakan dalam penelitian komposit epoxy aluminiumserbuk tempurung kelapa untuk kampas rem, yaitu : Mesin Flat And Disk, Alat Portable Hardness Tester TH120, Furnace, Timbangan Digital, Ayakan $600 \mu \mathrm{m}, 425 \mu \mathrm{m}$, dan $300 \mu \mathrm{m}$, Cetakan spesimen dengan diameter $25 \mathrm{~mm}$ dan tinggi 80 mm, dan Kertas Gosok/Amplas.

\section{HASIL DAN PEMBAHASAN}

Dari penelitian kampas rem komposit epoksi aluminium serbuk tempurung kelapa ,aluminium yang digunakan pada penelitian berfungsi meningkatkan kekerasan kampas rem komposit epoksi aluminium-serbuk tempurung kelapa karena memiliki nilai kekerasan $256 \mathrm{MPa}$ dibandingkan dari pada kekerasan tempurung kelapa dengan nilai 50 $80 \mathrm{MPa}$. Serbuk tempurung kelapa dapat meningkatkan laju keausan dari kampas rem komposit epoksi aluminium serbuk tempurung kelapa karena mempunyai kadar air dan serat sehingga lebih lunak dari pada serbuk aluminium. Selain itu ketahanan panas juga mempengaruhi kekerasan dan laju keausan dari kampas rem komposit epoksi aluminium serbuk tempurung kelapa, dimana semakin kecil ketahanan panas dari kampas rem, maka akan semakin kecil nilai laju keausan dan semakin kecil juga nilai kekerasannya.

\section{Pengujian Kekerasan}

Ukuran dari serbuk tempurung kelapa juga mempengaruhi kekerasan dan laju keausan dari kampas rem komposit epoksi aluminium serbuk tempurung kelapa. Dimana ukuran serbuk yang kecil mempunyai nilai kekerasan yang besar dan nilai laju keausan yang kecil dari pada ukuran serbuk yang lebih besar. Pengujian kekerasan menggunakan mesin uji kekerasan Portable Hardness Tester TH120, sehingga di peroleh hasil sebagai berikut (Gambar 3).

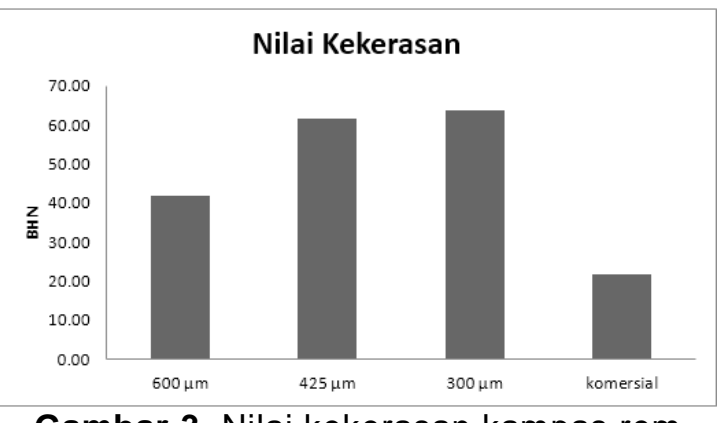

Gambar 3. Nilai kekerasan kampas rem komposit epoxy aluminium-serbuk tempurung kelapa

Nilai standart kekerasan kampas rem komposit yaitu 68 - 105 BHN [4]. Kampas rem komposit epoxy aluminium- serbuk tempurung kelapa dengan ukuran $300 \mu \mathrm{m}$ dan $425 \mu \mathrm{m}$, memenuhi nilai standar kekerasan kampas rem komposit yaitu dengan nilai kekerasan 61,67 BHN untuk kampas rem serbuk tempurung kelapa dengan ukuran $425 \mu \mathrm{m}$; dan 63,66 BHN untuk kampas rem serbuk tempurung kelapa dengan ukuran $300 \mu \mathrm{m}$. Dari data penelitian diketahui bahwa kekerasan dari disk brake yaitu 361 BHN, dimana nilai kekerasan disk brake lebih besar dari pada kekerasan kampas rem komposit epoxy aluminium-serbuk tempurung kelapa, sehingga yang di korbankan ketika terjadi gesekan adalah kampas rem komposit[5]. Dari hasil penelitian kampas rem komposit dapat dilihat bahwa semakin besar mesh dari bahan penyusun maka semakin besar nilai kekerasannya dan semakin baik struktur mikronya. Hal ini relevan dengan pernyataan bahwa; semakin keras suatu bahan semakin baik struktur mikronya serta semakin kecil nilai keausannya[6]. 
Dari data hasil penelitian kekerasan kampas rem komposit epoxy aluminiumserbuk tempurung kelapa dapat dilihat bahwa ukuran partikel dari bahan penyusun mempengaruhi kekerasan kampas rem komposit, sebab semakin kecil ukuran partikel bahan penyusun maka semakin kuat pula ikatan yang terbentuk diantar partikel bahan penyusunnya. Hal ini relevan dengan penelitian bahwah ukuran serbuk yang lebih besar berpengaruh pada distribusi partikel sehingga semakin kecil ukuran partikel semakin besar nilai kekerasannya karena distribusi partikel pada mesh yang lebih kecil memiliki distribusi partikel yang lebih baik[7]. Dari data hasil penelitian juga diketahui bahwa kampas rem epoxy aluminium-serbuk tempurung kelapa dengan ukuran $600 \mu \mathrm{m}, 425$ $\mu \mathrm{m}$, dan $300 \mu \mathrm{m}$, memiliki kekerasan lebih besar dari kampas rem komersial, hal ini disebabkan oleh pengaruh pada proses kompaksi dan sintering yang dilakukan selama proses pembuatan yang menyebabkan porositas berkurang dan bahan menjadi lebih kompak. Hal ini sesuai dengan pernyataan bahwa, nilai kekerasan suatu bahan juga terpengaruh oleh besar waktu penekanan kompaksi yang diberikan dalam proses pembuatan bahan kampas rem [8].

Dari hasil data kekerasan kampas rem komposit epoxy aluminium-serbuk tempurung kelapa dapat ditarik kesimpulan bahwa semakin kecil ukuran serbuk dari serbuk tempurung kelapa, maka semakin besar pula nilai kekerasannya. Hal ini sesuai dengan hipotesis yaitu semakin kecil ukuran serbuk dari bahan penyusun, maka semakin besar nilai kekerasan.

\section{Pengujian Laju Keausan}

Pengujian laju keausan yang dilakukan bertujuan untuk mengetahui nilai laju keausan dari kampas rem komposit epoxy aluminiumserbuk tempurung kelapa. Pengujian laju keausan menggunakan mesin uji flat and disk sehingga di peroleh hasil sebagai berikut. Dibawah ini pada gambar 4 akan dijelaskan hasil pengujian laju keausan.

Dari hasil penelitian kampas rem komposit dapat dilihat bahwa semakin kecil mesh dari bahan penyusun maka semakin besar nilai laju keausannya dan semakin baik struktur mikronya. Hal ini relevan dengan pernyataan [6], Semakin keras suatu bahan semakin baik struktur mikronya serta semakin kecil nilai laju keausannya. Nilai laju keausan kampas rem komposit epoxy aluminiumserbuk tempurung kelapa dengan ukuran 600 $\mu \mathrm{m}, 425 \mu \mathrm{m}$, dan $300 \mu \mathrm{m}$ lebih kecil dibandingkan kampas rem komersial, hal ini disebabkan oleh sedikitnya waktu yang diberikan pada proses kompaksi. Laju keausan suatu bahan komposit semakin besar atau semakin mudah aus dapat dipengaruhi oleh besarnya waktu yang diberikan pada proses kompaksi [9].

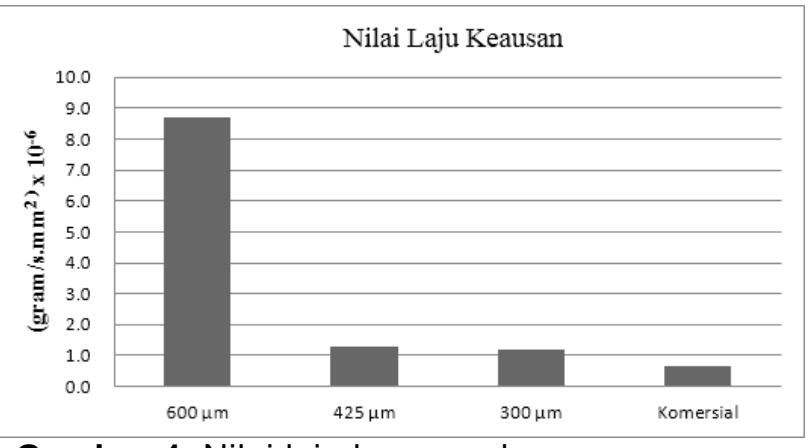

Gambar 4. Nilai laju keausan kampas rem komposit epoxy aluminium-serbuk tempurung kelapa

Penyebab lain nilai laju keausan kampas rem komposit epoxy aluminium-serbuk tempurung kelapa dengan ukuran $600 \mu \mathrm{m}, 425$ $\mu \mathrm{m}$ dan $300 \mu \mathrm{m}$, lebih kecil dibandingkan kampas rem komersial adalah semakin tinggi suhu sintering maka semakin kecil pula nilai laju keausannya begitu juga sebaliknya [8]. Dari data hasil penelitian diketahui bahwa kampas rem epoxy aluminium-serbuk tempurung kelapa dengan ukuran $425 \mu \mathrm{m}$ dan $300 \mu \mathrm{m}$ memiliki kekerasan lebih kecil dari kampas rem komersial, hal ini disebabkan oleh pengaruh pada proses kompaksi dan sintering yang dilakukan selama proses pembuatan yang menyebabkan porositas berkurang dan bahan menjadi lebih kompak. Nilai kekerasan suatu bahan juga terpengaruh oleh besar waktu penekanan kompaksi yang diberikan dalam proses pembuatan bahan kampas rem.

Dari data hasil penelitian laju keausan kampas rem komposit epoxy aluminiumserbuk tempurung kelapa dapat dilihat bahwa ukuran partikel dari bahan penyusun mempengaruhi laju keausan kampas rem 
komposit, sebab semakin kecil ukuran partikel bahan penyusun maka semakin kuat pula ikatan yang terbentuk diantar partikel bahan penyusunnya sehingga nilai laju keausannya semakin kecil. Dari hasil data laju keausan kampas rem komposit epoxy aluminiumserbuk tempurung kelapa dapat ditarik kesimpulan bahwa semakin kecil ukuran serbuk dari serbuk tempurung kelapa, maka semakin kecil pula nilai laju keausannya. Hal ini sesuai dengan hipotesis yaitu semakin kecil ukuran serbuk dari bahan penyusun, maka semakin kecil nilai laju keausannya.

\section{Pengujian Mikro}

Struktur mikro adalah gambaran dari kumpulan fasa-fasa yang dapat diamati melalui teknik metalografi. Struktur mikro suatu logam dapat dilihat dengan menggunakan mikroskop. Mikroskop yang dapat digunakan yaitu mikoroskop optik dan mikroskop elektron. Untuk mengetahui sifat dari suatu logam, kita dapat melihat struktur mikronya. Setiap logam dengan jenis berbeda memiliki struktur mikro yang berbeda. Dengan melalui diagram fasa, kita dapat meramalkan struktur mikronya dan dapat mengetahui fasa yang akan diperoleh pada komposisi dan temperatur tertentu. Dan dari struktur mikro kita dapat melihat ukuran dan bentuk butir, distribusi fasa yang terdapat dalam material khususnya logam, dan pengotor yang terdapat dalam material. Dari struktur mikro kita juga dapat memprediksi sifat mekanik dari suatu material sesuai dengan yang kita inginkan. Pengujian struktur mikro pada penelitian dari kampas rem komposit epoksi aluminium-serbuk tempurung kelapa menggunakan optikal mikroskop sehingga di peroleh hasil sebagai berikut. Dibawah ini pada gambar 5 akan dijelaskan hasil pengujian mikro.

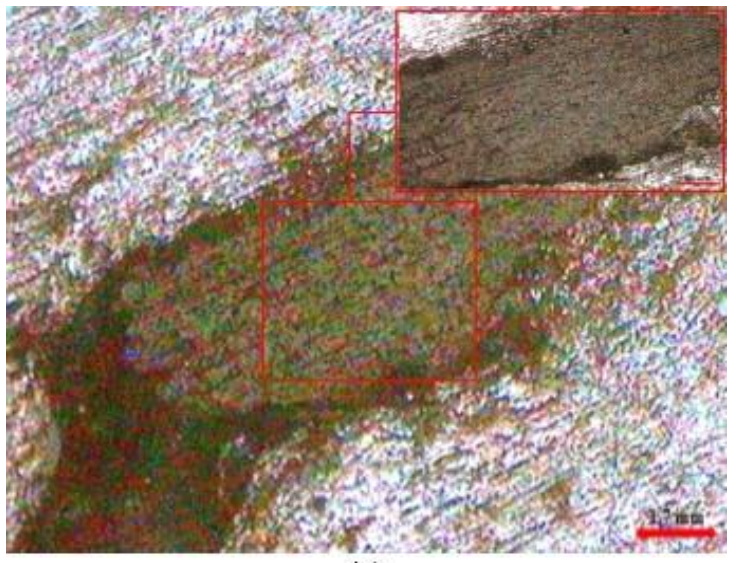

(a)

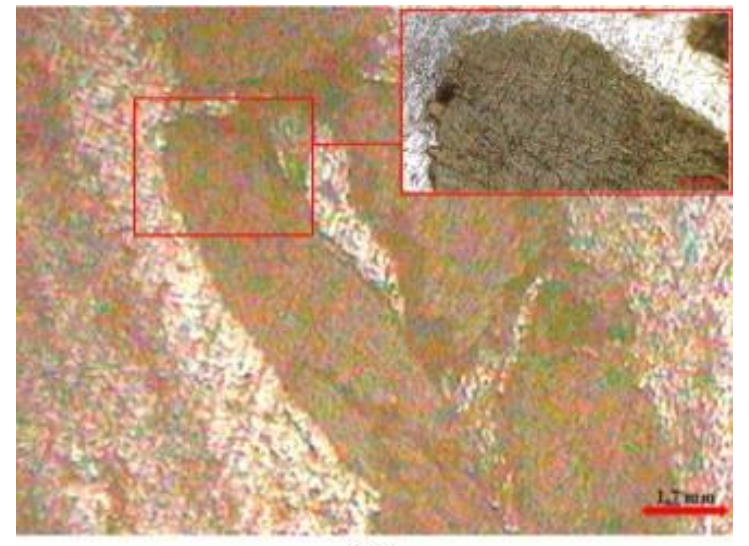

(b)

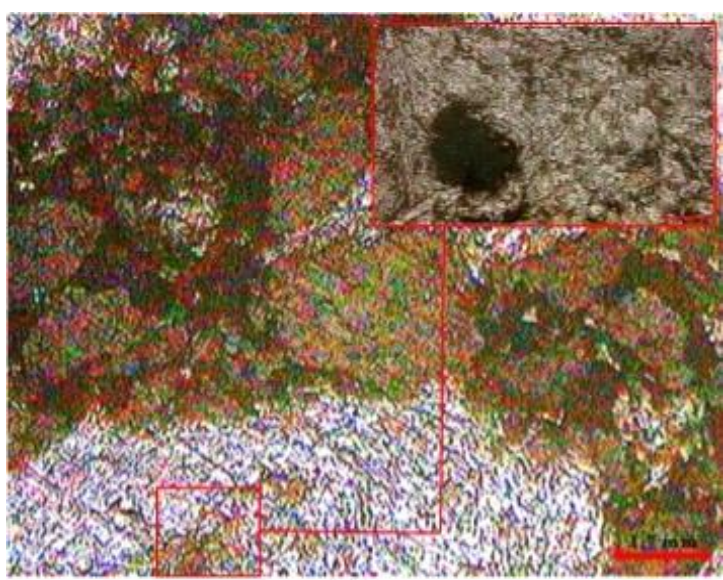

(c)

Gambar 5. Pengamatan struktur mikro kampas rem komposit epoxy aluminiumserbuk tempurung kelapa dengan ukuran:

(a) $600 \mu \mathrm{m}$, (b) $425 \mu \mathrm{m}$, (c) $300 \mu \mathrm{m}$.

Pada foto mikro dengan ukuran $600 \mu \mathrm{m}$, $425 \mu \mathrm{m}$, dan $300 \mu \mathrm{m}$ mengunakan dua pembesaran, yaitu pembesaran 50x, dan 
100x. Gambar 5, menunjukkan hasil karakterisasi permukaan dengan mikroskop optik. Hal tersebut menunjukkan adanya pengaruh dari variasi ukuran serbuk tempurung kelapa pada komposit. Dari gambar 5, dapat dilihat bahwa ukuran serbuk tempurung kelapa dengan ukuran $600 \mu \mathrm{m}$ lebih besar dibandingkan ukuran serbuk tempurung kelapa dengan ukuran $425 \mu \mathrm{m}$ dan $300 \mu \mathrm{m}$. Pada gambar 5 juga dapat dilihat bahwa ukuran serbuk tempurung kelapa terkecil adalah serbuk tempurung kelapa dengan ukuran $300 \mu \mathrm{m}$.

Pada gambar hasil mikro diatas. Dapat dilihat bahwa warna putih merupakan serbuk aluminium dan serbuk tempurung kelapa berwarna coklat. Pada gambar 5 bagian (a) dan (b), serbuk aluminium mendominasi dari pemukaan komposit, sedangkan pada gambar 5 bagian (c), serbuk aluminium dan serbuk tempurung kelapa seimbang pada permukaan komposit.Pada gambar 5 , tidak nampak resin epoksi dikarenakan resin terikat pada serbuk aluminium dan serbuk tempurung kelapa sehingga tidak nampak pada gambar diatas. Pada gambar 5 bagian (c), serbuk tempurung kelapa dengan ukuran $300 \mu \mathrm{m}$ tersebar secara merata pada permukaan komposit dibandingkan dengan serbuk tempurung kelapa ukuran $600 \mu \mathrm{m}$ dan $425 \mu \mathrm{m}$. Persebaran serbuk tempurung kelapa yang merata pada komposit menyebabkan meningkatnya nilai kekerasan dan menurunnya nilai laju keausan.

\section{KESIMPULAN}

Dari hasil penelitian yang dilakukan dapat diambil kesimpulan sebagai berikut:

1. Nilai kekerasan terbesar yaitu pada ukuran serbuk tempurung kelapa ukuran $300 \mu \mathrm{m}$ sebesar 63.67 BHN, dan nilai kekerasan terkecil yaitu serbuk tempurung kelapa dengan ukuran $600 \mu \mathrm{m}$ sebesar 41.67BHN.

2. Nilai laju keausan terbesar yaitu pada serbuk tempurung kelapa dengan ukuran $600 \mu \mathrm{m}$ sebesar $8,70 \times 10^{-6} \mathrm{gram} / \mathrm{s} . \mathrm{mm}^{2}$, dan nilai laju keausan terkecil yaitu serbu tempurung kelapa ukuran $300 \mu \mathrm{m}$ sebesar $1,17 \times 10^{-6} \mathrm{gram} / \mathrm{s} . \mathrm{mm}^{2}$.

3. Dari pengamatan struktur mikro menunjukan persebaran serbuk tempurung kelapa yang merata adalah komposit dengan serbuk tempurung kelapa dengan ukuran $300 \mu \mathrm{m}$.

\section{DAFTAR PUSTAKA}

[1] Wahyudi, Didik, dkk. 2002. Optimasi Kekerasan Kampas Rem dengan Metode Desain Eksperimen. Surabaya: Universitas Kristen Petra.

[2] D. Kiswiranti, Sugianto, N. Hindarto, Sutikno. 2009. Pemanfaatan Serbuk Tempurung Kelapa Sebagai Alternatif Serat Penguat Bahan Friksi Non-Asbes Pada Kampas Rem Sepeda Motor. Semarang: Universitas Negeri Semarang(Unnes).

[3] Santoso, dkk. 2013. Studi Pemanfaatan Campuran Serbuk Tempurung KelapaAluminium Sebagai Material Alternatif Kampas Rem Sepeda Motor NonAsbestos. Surakarta: UNS.

[4] Syahid, Muhammad, dkk. 2011. Analisa Sifat Mekanik Polimer Matriks Komposit Berpenguat Fly Ash Batubara Sebagai Kampas Rem. Makasar: Universitas Hasanuddin.

[5] Siswanto, Beni. 2008. Analisa Perbandingan Disk Brake Produk Asli Terhadap Disk Brake Imitasi Pada Motor GL Pro. Jakarta: Universitas MercuBuana.

[6] Priyambodo, Bambang Hari, dan Palmiyanto, Martinus Heru. 2014. Pengaruh Variasi Komposisi Bahan Komposit Limbah Kulit Mete/Phenolic Dengan Penguat Skrap Alumunium Terhadap Sifat Fisik danMekanik Sebagai Bahan Alternative Kampas Rem Non Asbestos. Surakarta: Akademi Teknologi Warga Surakarta.

[7] Mubarrok, Muh Husni. 2014. Pengaruh Ujuran Serbuk Kuningan Terhadap Ketahanan Aus, Koefisien Gesek, dan Kekerasan Kampas Rem. Surakarta: Universitas MuhhammadiyahSurakarta.

[8] Imam, Pramuko I.P, Dkk 2009. Pengaruh Komposisi Serat Kelapa Terhadap Kekerasan, Keausan Dan Koefisien Gesek Bahan Kopling Gesek Kendaraan. Surakarta: Universitas Muhammadiyah.

[9] Irfan, Pramuko, 2009, Pengaruh Variasi Tekanan Kompaksi Terhadap Ketahanan Kampas Rem Gesek Sepatu. Surakarta: Universitas Muhammadiyah Surakarta. 